Article

\title{
Construction of a Hydrogel Pectin-Based Triglyceride Optical Biosensor with Immobilized Lipase Enzymes
}

\author{
Uswatun Hasanah ${ }^{1,2}$, Nor Diyana Md Sani ${ }^{3}$, Lee Yook Heng ${ }^{4}$, Rinaldi Idroes ${ }^{5,6}$ and \\ Eka Safitri ${ }^{5, *}$ \\ 1 Graduate School of Mathematics and Applied Sciences, Universitas Syiah Kuala, Banda Aceh 23111, \\ Indonesia; uswatun.hasanah@utu.ac.id \\ 2 Department of Fisheries, Faculty of Fisheries and Marine Sciences, Universitas Teuku Umar, \\ West Aceh 23615, Indonesia \\ 3 Sanichem Resources Sdn. Bhd. No 7 \& 7A Jalan Timur 6/1A Mercato @Enstek, Bandar Enstek NSN 71060, \\ Malaysia; diyanasani@yahoo.com \\ 4 School of Chemical Sciences and Food Technology, Faculty of Science and Technology, Universiti \\ Kebangsaan Malaysia, Bangi SGR 43600 UKM, Malaysia; leeyookheng@yahoo.co.uk \\ 5 Department of Chemistry, Faculty of Mathematics and Natural Sciences, Universitas Syiah Kuala, Banda \\ Aceh 23111, Indonesia; rinaldi.idroes@unsyiah.ac.id \\ 6 Department of Pharmacy, Faculty of Mathematics and Natural Sciences, Universitas Syiah Kuala, \\ Banda Aceh 23111, Indonesia \\ * Correspondence: e.safitri@unsyiah.ac.id; Tel.: +62-853-7282-9295
}

Received: 24 August 2019; Accepted: 5 November 2019; Published: 13 November 2019

\begin{abstract}
A novel and simple optical biosensor to detect triglycerides (TGs) has been successfully constructed by using pectin hydrogel membrane as the indicator $\mathrm{pH}$ and chromoionophore ETH 5294 (CI), with lipase as the catalyst. The enzymatic working system against TGs releasing $\mathrm{H}^{+}$ions will affect the color absorbance of CI. The characterization results show that a TG biosensor has the optimum condition and sensitivity at the phosphate buffer concentration of $50 \mathrm{mM}, \mathrm{pH} 7$, and enzyme loading of $60 \mu \mathrm{g}$. The biosensor works at the tripalmitin (TP) concentration range of 100-400 mg/dL. With the sensitivity of $0.001(\Delta \mathrm{A} /(\mathrm{mg} / \mathrm{dL}))$, the biosensor response reaches stability after five minutes, and the limit of detection (LOD) of the TG optical biosensor is $15 \mathrm{mg} / \mathrm{dL}$. Relative standard deviation (RSD) in a reproducibility test was $2.5 \%$, with a 15 -day lifespan.
\end{abstract}

Keywords: triglyceride optical biosensor; pectin; chromoionophore

\section{Introduction}

A triglyceride (TG), also known as a type of biolipid, is a triester of glycerol bound to three fatty acids, with varying saturation degrees between 0 and 6 [1]. TGs play an important role in cellular metabolism as an energy source for dietary lipid transportation [2]. In the human body, TGs are a health indicator, where their normal serum concentration range is from 40 to $150 \mathrm{mg} / \mathrm{dL}$ [3]. Elevated TG concentrations in the body may result in cardiovascular and coronary heart diseases [4-7]. Therefore, due to this health concern, more effective ways to determine TG concentrations in food, beverage, and cosmetic products must be studied.

At present, with the rapid advancement of science and technology, cutting-edge equipment has been developed for the detection of TGs. These include colorimetry [8,9], spectrophotometry [10-14], chromatography [15,16], fluorometry [17], titrimetry [18], nuclear magnetic resonance [19], and enzymatic colorimetry [20]. Nevertheless, most of this mainstream equipment operates in a timeconsuming and expensive fashion, not to mention requiring highly skilled technicians. Therefore, a simple and selective avant-garde method for TG analysis is in high demand. Biosensors have received 
considerable attention from researchers for qualitative TG analysis of late. Scientists are particularly interested in looking into employing electrochemical analysis techniques [21-23], using multienzyme working systems [24,25] to develop these biosensors.

Previous electrochemical TG biosensor design has included TG measurement based on pH change from the hydrolysis of triglycerides by enzymes [26,27]. However, the change of $\mathrm{pH}$ in a potentiometric system will be highly affected by the presence of interference ions in a sample. Hence, we have chosen to construct an optical biosensor instead, so that this flaw will be eliminated, and our biosensor will be unaffected by ionic interferences.

In the construction of a biosensor, the immobilizing matrix plays an important role in maintaining biosensor stability during an analyte reaction and imparting a longer shelf life. A biosensor matrix can be constructed from synthetic and inorganic polymers, such as silicon [28-30] and polyvinyl chloride [31]. However, membranes from synthetic materials possess inefficient permeability, and in the long run are detrimental to the environment. Hence, biopolymeric materials like pectin [32] will be an excellent choice for a biosensor matrix. Biopolymers are superior in terms of biocompatibility, capability of enzyme absorption, thermal stability, and not to mention environmentally friendliness. Pectin, for instance, has been recognized for its hydrogel properties, which can facilitate the interaction of the active compounds and analytes within the matrix [32,33].

In this research, we report the development of a triglyceride, optical, bio-enzymatic biosensor, using pectin hydrogel membrane as its enzyme immobilizing matrix and containing chromoionophore ETH 5294 (CI) as a pH indicator. The hydrogel membrane is prepared with pectin, crosslinked with $\mathrm{CaCl}_{2}$ and $\mathrm{CI}$ as the first layer. The second layer consists of lipase enzymes immobilized via entrapment, which acts as the specific biocatalyst for TG hydrolysis. The products of TG hydrolysis by lipase are glycerol and fatty acids.

The enzymatic reaction is known to produce $\mathrm{H}^{+}$ions from fatty acids, leading to a $\mathrm{pH}$ change that causes the CI to be protonated. CI changes color from pink (deprotonated form) to blue (protonated form) on the pectin hydrogel membrane surface, and can be observed with a UV-VIS spectrophotometer. To the best of our knowledge, there is no research reporting triglyceride determination using a biosensor based on optical calculations. The design of the TG optical biosensor is illustrated in Figure 1.

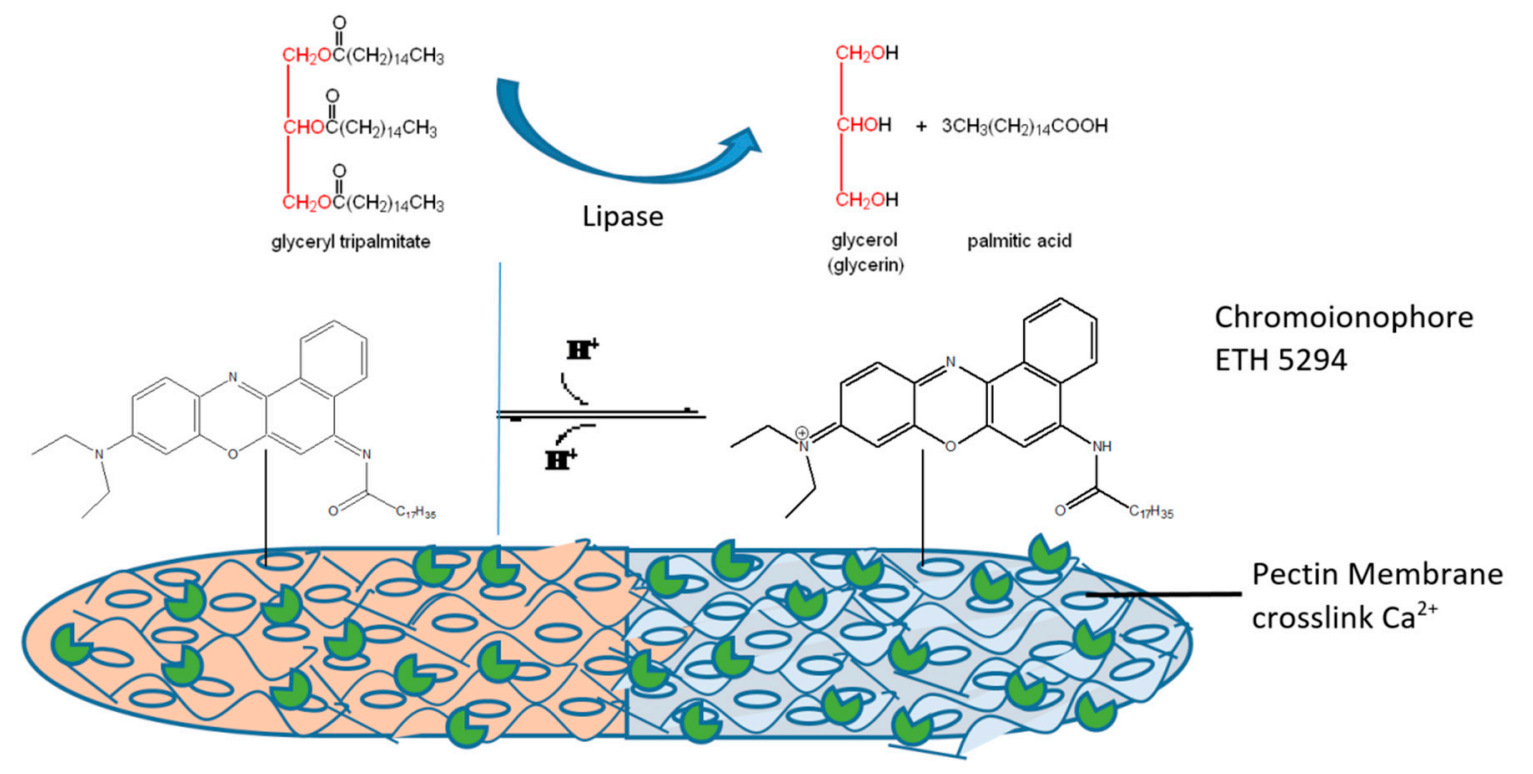

Figure 1. Triglyceride optical biosensor, developed from immobilized lipase enzymes via entrapment and adsorption on the pectin hydrogel membrane surface. 


\section{Materials and Methods}

\subsection{Materials and Instruments}

Chemicals used in this research include $\mathrm{CI}$, monopotassium dihydrogen phosphate $\left(\mathrm{KH}_{2} \mathrm{PO}_{4}\right)$, dipotassium phosphate $\left(\mathrm{K}_{2} \mathrm{HPO}_{4}\right)$ from Fluka (Steinhem, Germany) and Candida antartica lipase $\mathrm{b}$ enzyme from Aspergillus oryzae ( 9 U/Mg), as well as Glycerol tripalmitin (TP) $\geq 85 \%$, pectin, absolute ethanol $\left(\mathrm{C}_{2} \mathrm{H}_{5} \mathrm{OH}\right)$, and calcium chloride $\left(\mathrm{CaCl}_{2}\right)$ from Sigma Aldrich (St Louis, MO, USA).

The absorbance signal from the biosensor was determined by a Shimazu 1800 UV-VIS spectrophotometer (Kyoto, Japan) and pH buffer controlled with a Thermo Orion Star A2115 pH meter (Waltham, MA, USA). The pectin membrane surface morphology was analyzed with a Zeiss Merlin/Merlin/Gemini'2 Compact/Supra 55VP (Carl Zeiss, Jena, Germany) field emission scanning electron microscopy (FESEM).

\subsection{Reagent and Solution}

The CI reagent was prepared by dissolving $0.4 \mathrm{mg}$ CI in $1 \mathrm{~mL}$ ethanol and mixing for $10 \mathrm{~min}$ until homogenous. Potassium phosphate buffer solution (PBS) was prepared by mixing monopotassium dihydrogen phosphate $\left(\mathrm{KH}_{2} \mathrm{PO}_{4}\right)$ with dipotassium hydrogen phosphate $\left(\mathrm{K}_{2} \mathrm{HPO}_{4}\right)$. The TP stock solution was prepared by diluting TP stock solution with PBS $10 \mathrm{mM}$ at $\mathrm{pH}$. Enzyme lipase solution is prepared by dissolving $2 \mathrm{mg}$ lipase in $1000 \mu \mathrm{L}$ PBS $10 \mathrm{mM}(\mathrm{pH} 7)$, stored in a freezer at $4{ }^{\circ} \mathrm{C}$. The $2 \%$ hydrogel membrane solution is prepared by mixing 2 grams of pectin into $100 \mathrm{~mL} \mathrm{CaCl}_{2}$ solution $0.1 \mathrm{M}$. $\mathrm{CaCl}_{2}$ 0.1 M solution is prepared by dissolving $\mathrm{CaCl}_{2}$ into PBS $0.01 \mathrm{M}$ solution at $\mathrm{pH} 7$ and heating at $60{ }^{\circ} \mathrm{C}$ for $30 \mathrm{~min}$ while stirring until homogenous.

\subsection{Preparation of Triglyceride Optical Biosensor and Biosensor Response Optimization}

Our TG optical biosensor was prepared as illustrated by Hasanah et al. [33], with modifications. The TG optical biosensor had two layers: the bottom layer was the $\mathrm{pH}$ optical sensor, consisting of CI contained in a pectin membrane (Pectin/CI); meanwhile, the upper layer consisted of lipase enzyme solution. The bottom layer was obtained by dissolving $1 \mathrm{~mL}$ pectin $2 \%$ and the addition of $400 \mu \mathrm{L}$ CI solution, which was mixed for 10 min until homogenous. A total of $55 \mu \mathrm{L}$ of this pectin membrane/CI solution was added onto the surface of a plastic sheet, creating a circle $8 \mathrm{~mm}$ in diameter, and was left to dry overnight at room temperature $\left(25^{\circ} \mathrm{C}\right)$. Next, $30 \mu \mathrm{L}$ lipase enzyme solution was coated onto the dried pectin membrane/CI layer and stored in refrigerator for $24 \mathrm{~h}$ at $4{ }^{\circ} \mathrm{C}$. Before use, the $\mathrm{pH}$ optical sensor was first converted into its deprotonated form, using TP and PBS $1 \mathrm{M}$ buffer at pH 9. All parameters were conducted using three replicate biosensors. In addition, this biosensor was designed as a disposable, and will not be reused. The biosensor also does not require immersion in a sample, and it only involves dropping small amount of sample $(40 \mu \mathrm{L})$ onto the surface of the biosensor.

The effect of PBS buffer concentration on the TG biosensor is determined by varying PBS concentrations of 10,50 , and $100 \mathrm{mM}$ at $\mathrm{pH} 7$ and TP concentration from 100-500 mg/dL, measured at a wavelength of $615 \mathrm{~nm}$.

TG biosensor response optimization against the $\mathrm{pH}$ change was determined using PBS $50 \mathrm{mM}$ and a TP concentration of $100-500 \mathrm{mg} / \mathrm{dL}$, at a range of $\mathrm{pH} 6-8$.

In order to evaluate the effect of lipase enzyme concentration against the TG biosensor, the lipase concentration was varied between 20-100 $\mu$ g at a TP concentration of $400 \mathrm{mg} / \mathrm{dL}$ in PBS buffer $50 \mathrm{mM}$, at $\mathrm{pH} 7$.

The response time of the TG biosensor was determined by measuring the biosensor response every minute for $10 \mathrm{~min}$ at $400 \mathrm{mg} / \mathrm{dL}$ TP concentration 


\subsection{Triglyceride Optical Biosensor Performance Characterization}

The performance of the TG optical biosensor probe was evaluated using a few parameters, including dynamic linear range, the limit of detection (LOD), storage stability of the TG biosensor, and its reproducibility.

The dynamic linear range of the TG optical biosensor was constructed against increasing TP as the triglyceride, with concentrations in the range of $100 \mathrm{mg} / \mathrm{dL}$ to $500 \mathrm{mg} / \mathrm{dL}$ in $50 \mathrm{mM}$ PBS at pH 7 . This was followed by the LOD, where three blank absorbance values were taken and calculated based on the equation.

$$
\mathrm{LOD}=3 S D / S
$$

where $S D$ is the standard deviation of the blank values and $S$ is the slope of the plotted concentration of TP from 100-400 mg/dL versus absorbance using an optimized biosensor.

Next, in order to evaluate the storage stability of this TG biosensor, 50 TG biosensors are produced and stored in a refrigerator at $4{ }^{\circ} \mathrm{C}$. The biosensors were measured periodically, where during each measurement, three biosensors were used. These biosensors were tested with a TP concentration of $400 \mathrm{mg} / \mathrm{dL}$ in $50 \mathrm{mM}$ PBS pH 7 for 25 days.

The reproducibility of the TG biosensor is evaluated by measuring 10 TG biosensors and calculating their relative standard deviation (RSD) and sensitivity values.

\section{Results and Discussion}

\subsection{Characterization of Pectin Hydrogel Membrane}

Pectin hydrogel membrane is made with a $\mathrm{CaCl}_{2}$ crosslinker. $\mathrm{Ca}^{2+}$ ions can induce pectin to be crosslinked when $\mathrm{CaCl}_{2}$ is inserted into pectin solution, thus forming a gel. The obtained hydrogel membrane is colorless, and morphological observation with scanning electron microscopy (SEM) shows that the pectin membrane is homogenous, giving it a smooth surface, which is important for the absorbance value consistency (Figure 2a). On the other hand, $\mathrm{CI}$ is added into the pectin hydrogel membrane as an indicator, with lipase enzyme acting as the catalyst for TG biosensor. As seen in Figure 2b, the morphology of a pectin hydrogel membrane changes when lipase is present on the membrane surface.

An X-ray diffraction (XRD) analysis was performed to confirm the amorphous structure of pure pectin and the pectin hydrogel membrane. Here, the peaks for pectin were at $2 \theta \approx 39$ and 43 , with the intensities of 68 and 256, respectively. Meanwhile, the peaks obtained for pectin hydrogel membrane were at $2 \theta \approx 39$ and 43 , and the intensity decreased to 45 and 153, respectively. This can be ascribed to the more amorphous characteristic of the pectin hydrogel membrane compared to pure pectin. The diffractogram is displayed in Figure 2c. The elastic properties of the pectin hydrogel membrane were based on the result of a visual inspection, and are suitable as optical sensor matrices.

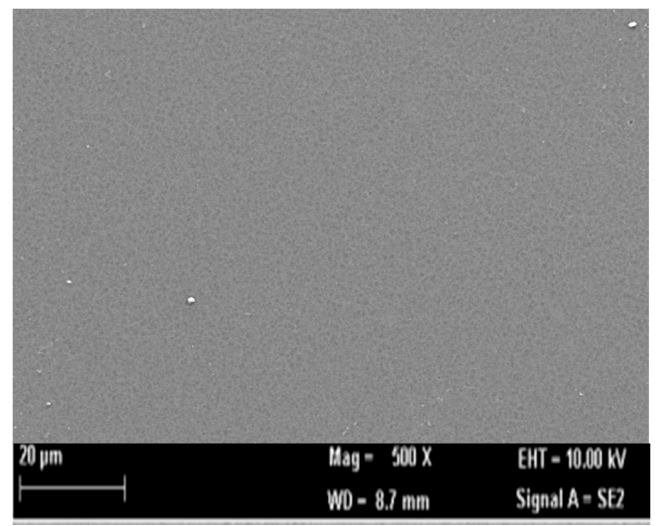

(a)

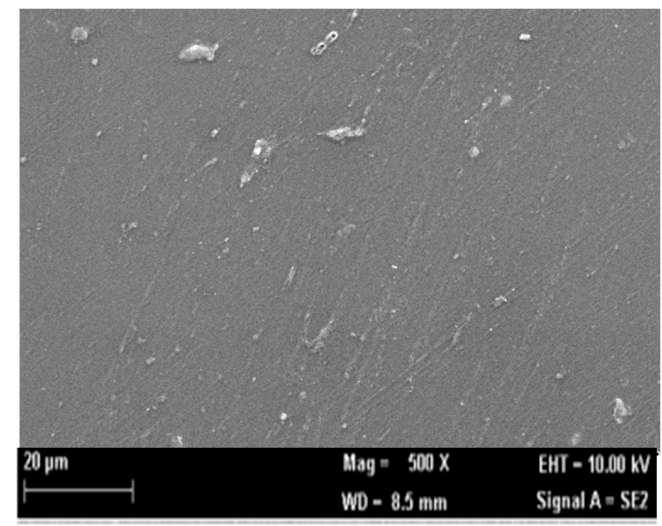

(b)

Figure 2. Cont. 


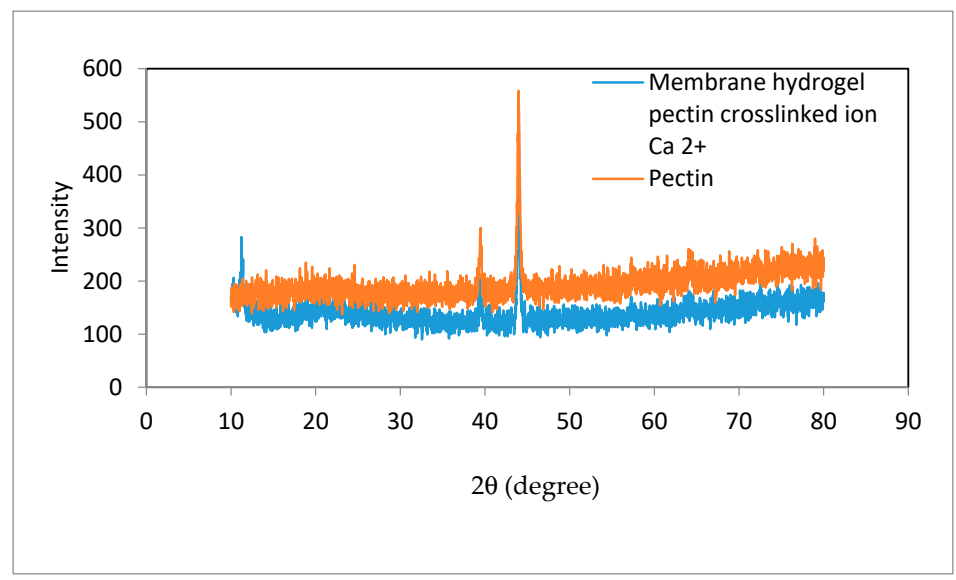

(c)

Figure 2. Characterization of pectin hydrogel membrane: (a) SEM morphology of pectin hydrogel membrane (pectin $+\mathrm{CaCl}_{2}+\mathrm{CI}$ ); (b) SEM morphology of a triglyceride (TG) optical biosensor membrane (pectin $+\mathrm{CaCl}_{2}+\mathrm{CI}+$ lipase); (c) Crystallinity diffractogram of pure pectin and pectin hydrogel membrane.

\subsection{The Response of a Triglyceride Optical Sensor Using a Pectin Hydrogel Membrane}

The construction of the TG optical biosensor consisted of the preparation of a $\mathrm{pH}$ optical sensor $[26,32]$ that was modified with the addition of a lipase enzyme. Lipase will catalyze the transformation of a TG into a fatty acid, which will be detected by the $\mathrm{pH}$ optical sensor.

The response of the $\mathrm{pH}$ optical sensor at $\mathrm{pH} 5-9$ has a sensitivity of $0.056\left(R^{2}=0.0986\right)$, where the color change of $\mathrm{CI}$ takes place against the change of $\mathrm{pH}$, as reported by Hasanah et al. [33]. This becomes the basis for TG determination of this optical biosensor, as a $\mathrm{pH}$ change will occur when lipase hydrolyzes TPs into fatty acids. The CI will undergo a change in color proportional to the increasing $\mathrm{TP}$ concentration as a result of this $\mathrm{pH}$ change, as shown by Figure 3.

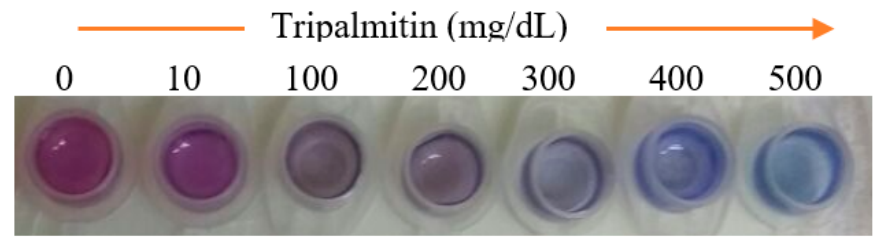

Figure 3. Color change of the TG biosensor at various concentration of tripalmitin (TP), a triglyceride, on a pectin hydrogel membrane.

\subsection{The Effect of Buffer Concentration, $\mathrm{pH}$, and Loading Enzyme Concentration against the Response of a Triglyceride Optical Biosensor}

As mentioned earlier, the upper layer of this TG biosensor consisted of a lipase enzyme solution. $\mathrm{TP}$, a triglyceride, was used as the substrate for this biosensor's characterization. A lipase enzyme will catalyze TG hydrolysis into fatty acids and glycerol [28]. The released acid results in a decrease in $\mathrm{pH}$, leading to a color change on the pectin hydrogel membrane from pink to blue. The absorbance of this color change can be measured at $\lambda_{\max }=615 \mathrm{~nm}$.

In addition, the $\mathrm{pH}$ change also depends on the strength of the ionic buffer $[19,20]$. The effect of buffer concentration against biosensor response is observed with PBS concentrations from 10-100 mM. The TG biosensor response against various PBS concentrations at $\mathrm{pH} 7$ is shown in Table 1 . A phosphate buffer with a concentration of $50 \mathrm{mM}$ gives the best linearity and sensitivity compared to other concentrations. In this case, buffer concentration of $50 \mathrm{mM}$ is the most suitable condition for lipase activation. Therefore, a phosphate buffer of $50 \mathrm{mM}$ was selected as the buffer concentration for the next optimization. 
Table 1. The effect of buffer concentration against sensitivity and determination coefficient $\left(R^{2}\right)$ of the TG biosensor at $615 \mathrm{~nm}$.

\begin{tabular}{cccc}
\hline $\begin{array}{c}\text { Buffer Concentration } \\
(\mathbf{m M})\end{array}$ & $\begin{array}{c}\text { TP Concentration } \\
(\mathbf{m g} / \mathbf{d L})\end{array}$ & $\begin{array}{c}\text { Sensitivity } \\
(\boldsymbol{\Delta} \mathbf{A} / \mathbf{m g} / \mathbf{d L})\end{array}$ & $\begin{array}{c}\text { Determination } \\
\text { Coefficient }\left(\boldsymbol{R}^{\mathbf{2}}\right)(\boldsymbol{n}=\mathbf{4})\end{array}$ \\
\hline 10 & $100-400$ & 0.0007 & 0.9612 \\
50 & $100-400$ & 0.001 & 0.9807 \\
100 & $100-400$ & 0.0008 & 0.9585 \\
\hline
\end{tabular}

The effect of environmental $\mathrm{pH}$ against the TG optical biosensor response at TP concentrations of 100-500 $\mathrm{mg} / \mathrm{dL}$ has been evaluated, in order to determine the optimum $\mathrm{pH}$ of biosensor's performance. Previous studies have reported that lipase works best at an optimal $\mathrm{pH}$ of between 6 and 8 [6,34].

Table 2 shows an increase of the biosensor response at $\mathrm{pH} 6-7$, but a decrease at $\mathrm{pH} 7.5$ and 8 . The decrease in biosensor sensitivity is caused by the change in the conformation of the enzyme binding sites, thus decreasing their function in degrading triglycerides [33]. In this study, the best sensitivity was given by $\mathrm{pH}$ 7-hence, $\mathrm{pH} 7$ is used for the upcoming characterization of the TG biosensor. This optimum $\mathrm{pH}$ is similar to studies reported before, which used amperometry and electrochemical methods [35,36]. However, a different optimum $\mathrm{pH}$ is reported by Narang et al. [37]. This difference can be caused by a different membrane matrix, type of substrate, enzyme, and immobilization method [38].

Table 2. The effect of $\mathrm{pH}$ buffer against the sensitivity and determination coefficient $\left(R^{2}\right)$ of the TG biosensor at $615 \mathrm{~nm}$.

\begin{tabular}{cccc}
\hline pH Buffer & $\begin{array}{c}\text { TP Concentration } \\
(\mathbf{m g} / \mathbf{d L})\end{array}$ & $\begin{array}{c}\text { Sensitivity } \\
(\mathbf{A} / \mathbf{m g} / \mathbf{d L})\end{array}$ & $\begin{array}{c}\text { Determination } \\
\text { Coefficient }\left(\boldsymbol{R}^{2}\right)(\boldsymbol{n}=\mathbf{4})\end{array}$ \\
\hline 6 & $100-400$ & 0.0006 & 0.9579 \\
6.5 & $100-400$ & 0.0008 & 0.9665 \\
7 & $100-400$ & 0.001 & 0.9809 \\
7.5 & $100-400$ & 0.0007 & 0.9513 \\
8 & $100-400$ & 0.0005 & 0.9165 \\
\hline
\end{tabular}

The biosensor response also depends on the number of immobilized enzymes within the matrix. The increase of enzyme has shown to increase the biosensor response. The profile of enzyme loading is shown in Figure 4. The biosensor response increased with enzyme concentrations of 20 to $60 \mu \mathrm{g}$, but decreased in response to enzyme loading above $60 \mu \mathrm{g}$. The increase causes the rate of TP hydrolysis into fatty acids to intensify as well. On the other hand, the decrease of biosensor response is due to the extreme $\mathrm{pH}$ change caused by a reaction, which inactivates the enzyme binding sites [39]. The dwindling response can also be ascribed to the excessive enzyme that inhibits substrate diffusion [38,40]. The highest response was obtained at enzyme lipase loading of $60 \mu \mathrm{g}$.

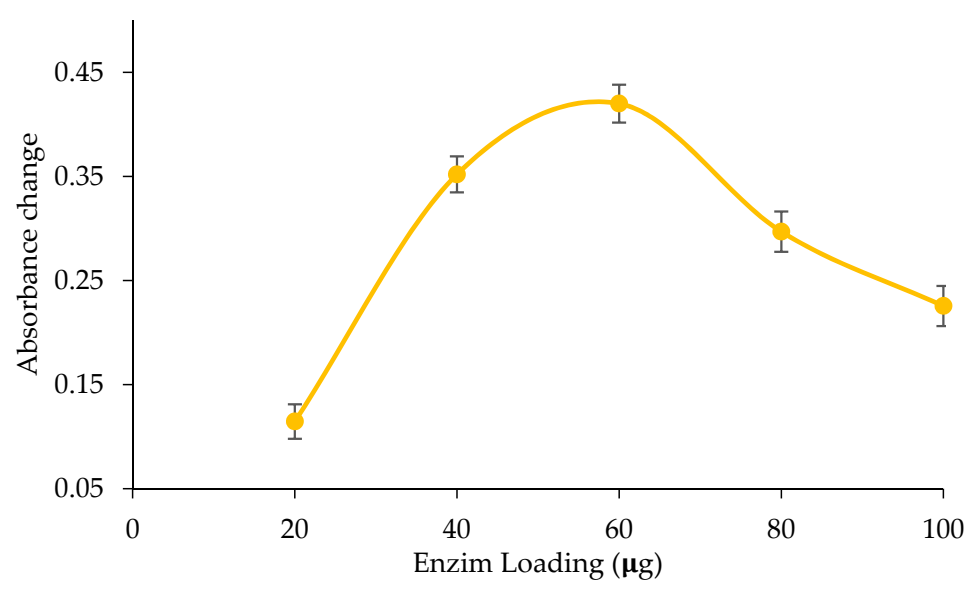

Figure 4. Profile lipase loading on the response biosensor. 


\subsection{Characterization of Triglyceride Optical Biosensor}

The response time of a biosensor indicates how fast it reacts to the change of external environment. The response time of this triglycerides biosensor is measured at a TP concentration of $400 \mathrm{mg} / \mathrm{dL}$ in PBS $50 \mathrm{mM}$ solution ( $\mathrm{pH} 7$ ). The determination of the response time was conducted every minute, as shown in Figure 5. The maximum time response is exhibited in the fifth minute, where afterward, the biosensor does not show any response changes. Therefore, it can be concluded that the optimal response time of this triglyceride biosensor is $5 \mathrm{~min}$. The quicker the response time, the more effective the biosensor. Response time can be affected by several factors, such as diffusion, enzymatic activities, loading enzyme, and enzyme immobilization mechanism [41].

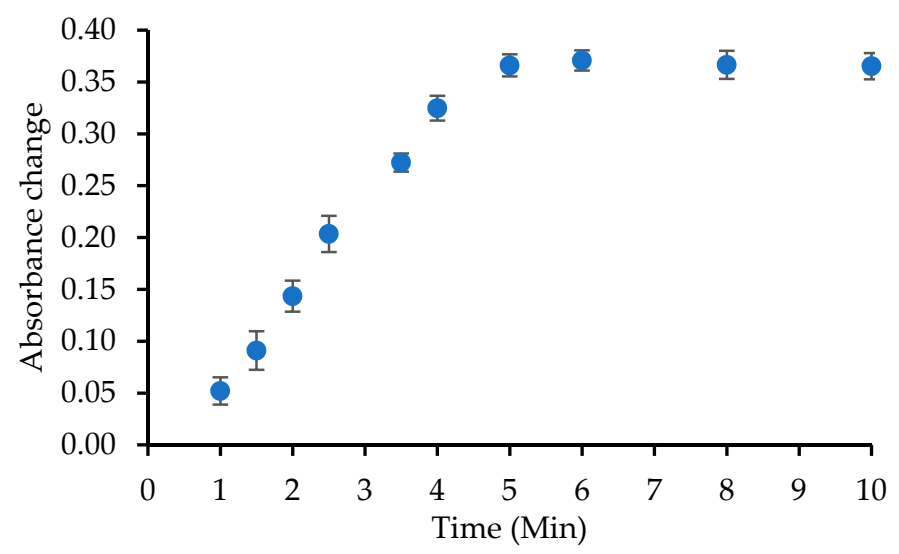

Figure 5. Response time of the TG biosensor.

The determination of the biosensor lifespan is necessary to identify its stability and durability during usage. The biosensor is made with the same concentration, where $400 \mathrm{mg} / \mathrm{dL}$ of TP was added and dissolved in $50 \mathrm{mM}$ PBS at pH 7. The lifespan was evaluated for 30 days. The results show that biosensor absorbance decreased $7.4 \%$ after 10 days of storage, $10.2 \%$ after 15 days of storage, and $24.2 \%$ after 25 days of storage. Therefore, it can be concluded that this TG biosensor can be used for up to 15 days of storage. The results of this lifespan study are shown in Figure 6.

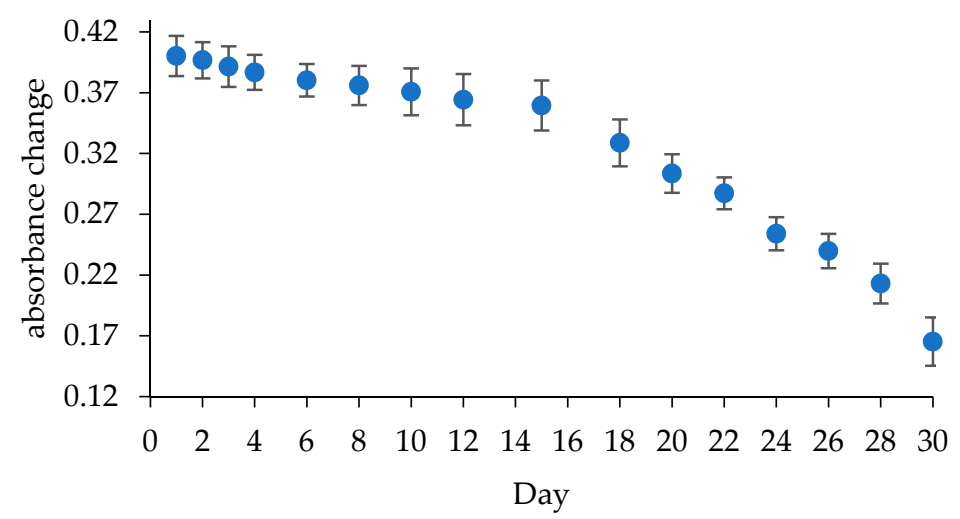

Figure 6. Profile of lifespan of the TG biosensor.

\subsection{Determination of Linearity, the Limit of Detection, and Reproducibility}

After all parameters that build this biosensor had been characterized, the linearity and limit of detection of this biosensor were finally determined. The biosensor response after the addition of TP from $100 \mathrm{mg} / \mathrm{dL}$ to $500 \mathrm{mg} / \mathrm{dL}$ can be observed in Figure 7a. The response of biosensor against TP increases linearly with an increasing concentration of TP. The increase of substrate in the biosensor membrane surface triggers the increase of TP degradation into fatty acids, thus causing color change 
on the hydrogel membrane from pink to blue. The response of the optical biosensor reaches a constant rate of $500 \mathrm{mg} / \mathrm{dL}$, because the occupied binding sites of the enzyme have reached saturation.

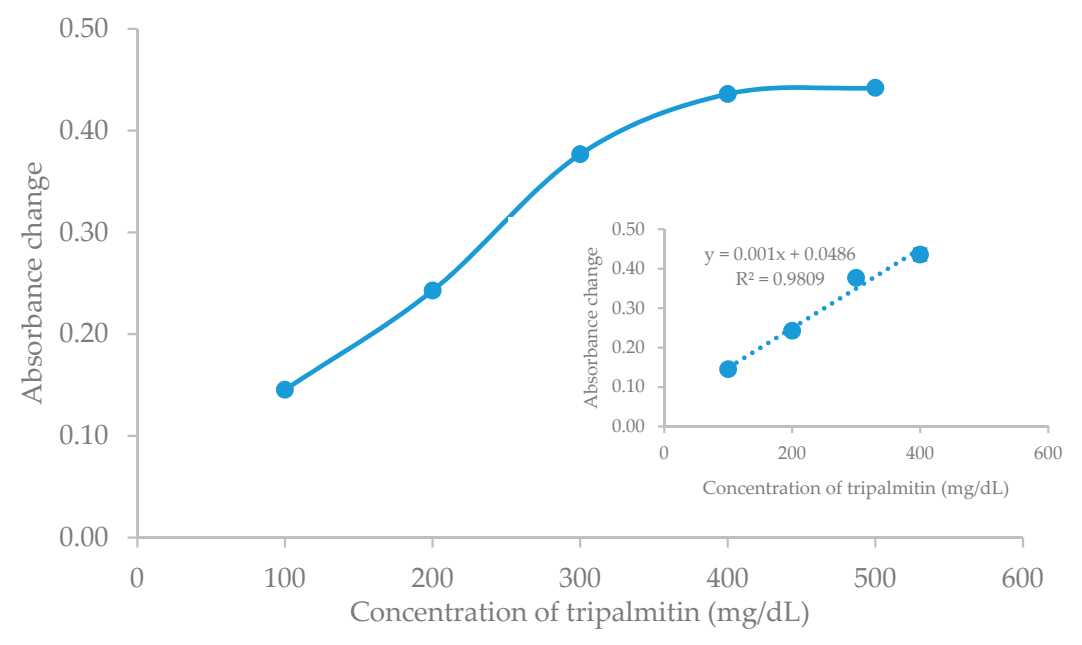

(a)

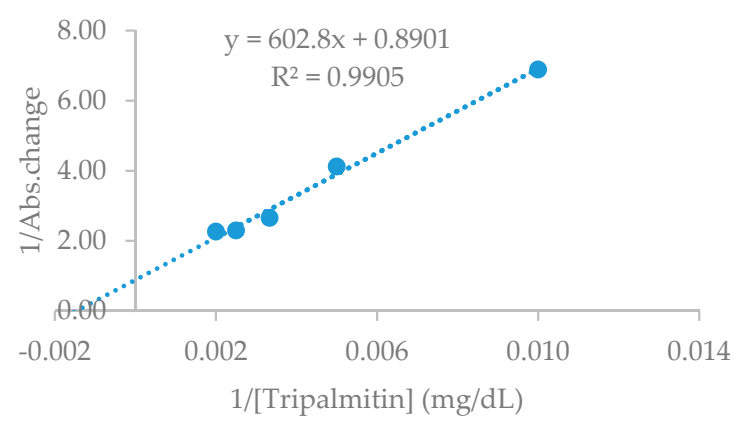

(b)

Figure 7. TG biosensor response against TP concentration: (a) Calibration curve of the TG biosensor; (b) Lineweaver-Burk plot of pectin hydrogel membrane-based TP concentration that is immobilized by enzyme and CI.

An approximate linear response of TG biosensor was determined at the range of 100-500 mg/dL of TP concentration, with 0.001 sensitivity $(100-400 \mathrm{mg} / \mathrm{dL})$ and $R^{2}=0.981(n=4)$. The limit of detection (LOD) is defined as the lowest TP concentration where there is no change in optical biosensor response. The LOD of the TP is estimated to be $15 \mathrm{mg} / \mathrm{dL}$.

The kinetic parameter of the enzymatic reaction can be calculated through a Lineweaver-Burk plot, based on the experimental data. The Michaelis-Menten $(\mathrm{Km})$ constant calculated from Lineweaver-Burk plot was $677 \mathrm{mg} / \mathrm{dL}(7.6 \mathrm{mM})$, and the $V \max =1.12$ (Figure $7 \mathrm{~b})$. Some researchers have reported that the $\mathrm{Km}$ value varies with the type of substrate and lipase immobilization matrix. Minakshi and Pundir [42] reported that the $K m$ value for lipase immobilized in the aryl amine matrix for the determination of a TG, using a plastic strips, was $11.6 \mathrm{mM}$. Furthermore, Narang et al. [29] determined the Km value of lipase in the polyvinyl chloride (PVC) matrix for the amperometric TG biosensor to be valued at $5.0 \mathrm{mM}$.

The reproducibility of a TG biosensor is measured by using 20 biosensors made with the same concentration and measured at the same time. The results indicate that this biosensor has a good reproducibility, as shown by the RSD value, which reached $2.5 \%$. This biosensor also exhibits good linearity, with more than $R^{2}=0.9$. 


\section{Conclusions}

A TG optical biosensor based on a pectin hydrogel membrane and CI was successfully established. All parameters required for the construction of this parameter have been optimally determined, resulting in an excellent linear response range towards TP in the TG concentration range of human blood serum. This biosensor is competent in detecting TGs promptly, and displays outstanding precision. This TG biosensor will be developed further to be used on real blood serum. We strongly believe the concept that this biosensor carries can also be used to design other biosensors that can detect more health indicators.

Author Contributions: Conceptualization, E.S. and U.H.; methodology, E.S.; software, R.I.; validation, E.S., U.H. and R.I.; formal analysis, L.Y.H.; investigation, U.H.; resources, U.H.; data curation, U.H., E.S., R.I. and L.Y.H.; writing-original draft preparation, U.H. and N.D.M.S.; writing—review and editing, U.H., E.S., R.I. and N.D.M.S.; visualization, U.H.; supervision, E.S., R.I. and L.Y.H.; project administration, R.I.; funding acquisition, U.H.

Funding: This research was funded by Kementerian Riset, Teknologi dan Pendidikan Tinggi Indonesia, grant number: 008/UN59.7/TL/2018.

Conflicts of Interest: The athours declare no conflict of interest.

\section{References}

1. Mondal, K.; Ali, M.A.; Singh, C.; Sumana, G.; Malhotra, B.D.; Sharma, A. Highly sensitive porous carbon and metal/carbon conducting nanofiber based enzymatic biosensors for triglyceride detection. Sensors Actuators B Chem. 2017, 246, 202-214. [CrossRef]

2. Dallongeville, J.; Meirhaeghe, A. Triglyceride-mediated pathways and coronary heart disease. Lancet (Lond. Engl.) 2010, 376, 956-958. [CrossRef]

3. De Lourdes Higuchi, M. Diagnosis, Prevention and Treatment of Disorders Characterized by Undesirable Cell Proliferation. U.S. Patent No. 8,551,940, 8 October 2013.

4. Solanki, P.R.; Dhand, C.; Kaushik, A.; Ansari, A.A.; Sood, K.N.; Malhotra, B.D. Nanostructured cerium oxide film for triglyceride sensor. Sens. Actuators B Chem. 2009, 141, 551-556. [CrossRef]

5. Narang, J.; Pundir, C.S. Construction of a triglyceride amperometric biosensor based on chitosan- $\mathrm{ZnO}$ nanocomposite film. Int. J. Biol. Macromol. 2011, 49, 707-715. [CrossRef] [PubMed]

6. Narang, J.; Chauhan, N.; Pundir, C.S. Construction of triglyceride biosensor based on nickel oxide-chitosan/zinc oxide/zinc hexacyanoferrate film. Int. J. Biol. Macromol. 2013, 60, 45-51. [CrossRef]

7. Panky, S.; Thandavan, K.; Sivalingam, D.; Sethuraman, S.; Krishnan, U.M.; Jeyaprakash, B.G.; Rayappan, J.B.B. Lipase immobilized on nanostructured cerium oxide thin film coated on transparent conducting oxide electrode for butyrin sensing. Mater. Chem. Phys. 2013, 137, 892-897. [CrossRef]

8. Mamoru, S.; Tsutomu, O.; Kazuyuki, H.; Hidemi, M.; Hiroko, Y.; Masayasu, S.; Taeko, K. A simple colorimetric method for determination of serum triglycerides with lipoprotein lipase and glycerol dehydrogenase. Clin. Chim. Acta 1977, 81, 125-130. [CrossRef]

9. Li, Z.; Suslick, K.S. Ultrasonic Preparation of Porous Silica-Dye Microspheres: Sensors for Quantification of Urinary Trimethylamine N -Oxide. ACS Appl. Mater. Interfaces 2018, 10, 15820-15828. [CrossRef]

10. Callejo'n Mocho'n, M.; Muñoz Leyva, J.A. A new spectrophotometric method for determining triglycerides in serum. Clin. Chim. Acta 1984, 142, 281-285. [CrossRef]

11. Lahna, K.; Idroes, R.; Idris, N.; Abdulmadjid, S.N.; Kurniawan, K.H.; Tjia, M.O.; Pardede, M.; Kagawa, K. Formation and emission characteristics of $\mathrm{CN}$ molecules in laser induced low pressure He plasma and its applications to $\mathrm{N}$ analysis in coal and fossilization study. Appl. Opt. 2016, 55, 1731. [CrossRef]

12. Hedwig, R.; Lahna, K.; Idroes, R.; Karnadi, I.; Tanra, I.; Iqbal, J.; Kwaria, D.; Kurniawan, D.P.; Kurniawan, K.H.; Tjia, M.O.; et al. Food analysis employing high energy nanosecond laser and low pressure He ambient gas. Microchem. J. 2019, 147, 356-364. [CrossRef]

13. Suhartono, E.; Noor, Z.; Edyson; Budianto, W.Y.; Idroes, R. Effect of Chronic Lead Exposure on Bone Using ATR-FTIR Spectroscopy. AIP Conf. Proc. 2019, 2108, 020025.

14. Lee, D.-K.; Kang, J.-H.; Lee, J.-S.; Kim, H.-S.; Kim, C.; Hun Kim, J.; Lee, T.; Son, J.-H.; Park, Q.-H.; Seo, M. Highly sensitive and selective sugar detection by terahertz nano-antennas. Sci. Rep. 2015, 5, 15459. [CrossRef] [PubMed] 
15. Brunnekreeft, J.W.; Leijnse, B. Determination of serum triglycerides by capillary on-column gas chromatography. J. Clin. Chem. Clin. Biochem. 1986, 24, 445-449. [CrossRef] [PubMed]

16. Earlia, N.; Rahmad, R.; Amin, M.; Prakoeswa, C.R.S.; Khairan, K.; Idroes, R. The Potential Effect of Fatty Acids from Pliek U on Epidermal Fatty Acid Binding Protein: Chromatography and Bioinformatic Studies. Sains Malays. 2019, 48, 1019-1024. [CrossRef]

17. Mendez, A.J.; Cabeza, C.; Hsia, S.L. A fluorometric method for the determination of triglycerides in nanomolar quantities. Anal. Biochem. 1986, 156, 386-389. [CrossRef]

18. Klotzsch, S.G.; McNamara, J.R. Triglyceride measurements: A review of methods and interferences. Clin. Chem. 1990, 36, 1605-1613.

19. Otvos, J. Measurement of triglyceride-rich lipoproteins by nuclear magnetic resonance spectroscopy. Clin. Cardiol. 1999, 22, II21-II27. [CrossRef]

20. Kalia, V.; Pundir, C.S. Determination of serum triglycerides using lipase, glycerol kinase, glycerol-3-phosphate oxidase and peroxidase co-immobilized onto alkylamine glass beads. Indian J. Biochem. Biophys. 2004, 41, 326-328.

21. Palchetti, I.; Laschi, S.; Mascini, M. Electrochemical biosensor technology: Application to pesticide detection. Methods Mol. Biol. 2009, 504, 115-126.

22. Batra, B.; Narwal, V.; Pundir, C.S. An amperometric lactate biosensor based on lactate dehydrogenase immobilized onto graphene oxide nanoparticles-modified pencil graphite electrode. Eng. Life Sci. 2016, 16, 786-794. [CrossRef]

23. Pundir, C.S.; Narwal, V. Biosensing methods for determination of triglycerides: A review. Biosens. Bioelectron. 2018, 100, 214-227. [CrossRef] [PubMed]

24. Khanna, V.K. New-generation nano-engineered biosensors, enabling nanotechnologies and nanomaterials. Sens. Rev. 2008, 28, 39-45. [CrossRef]

25. Yücel, A.; Özcan, H.M.; Sağıroğlu, A. A new multienzyme-type biosensor for triglyceride determination. Prep. Biochem. Biotechnol. 2016, 46, 78-84. [CrossRef]

26. Preetha, R.; Rani, K.; Veeramani, M.S.S.; Fernandez, R.E.; Vemulachedu, H.; Sugan, M.; Bhattacharya, E.; Chadha, A. Potentiometric estimation of blood analytes-Triglycerides and urea: Comparison with clinical data and estimation of urea in milk using an electrolyte-insulator-semiconductor-capacitor (EISCAP). Sens. Actuators B Chem. 2011, 160, 1439-1443. [CrossRef]

27. Fernandez, R.E.; Hareesh, V.; Bhattacharya, E.; Chadha, A. Comparison of a potentiometric and a micromechanical triglyceride biosensor. Biosens. Bioelectron. 2009, 24, 1276-1280. [CrossRef]

28. Reddy, R.R.K.; Chadha, A.; Bhattacharya, E. Porous silicon based potentiometric triglyceride biosensor. Biosens. Bioelectron. 2001, 16, 313-317. [CrossRef]

29. Narang, J.; Minakshi, B.M.; Pundir, C.S. Fabrication of an Amperometric Triglyceride Biosensor Based on PVC Membrane. Anal. Lett. 2009, 43, 1-11. [CrossRef]

30. Sahudin, M.A.; Su'ait, M.S.; Tan, L.L.; Lee, Y.H.; Abd Karim, N.H. Zinc(II) salphen complex-based fluorescence optical sensor for biogenic amine detection. Anal. Bioanal. Chem. 2019, 411, 6449-6461. [CrossRef]

31. Muslem, M.; Kuncaka, A.; Himah, T.N.; Roto, R. Preparation of Char-Fe ${ }_{3} \mathrm{O}_{4}$ Composites from Polyvinyl Chloride with Hydrothermal and Hydrothermal-Pyrolysis Carbonization Methods as Co(II) Adsorbents. Indones. J. Chem. 2019, 19, 835. [CrossRef]

32. Hasanah, U.; Setyowati, M.; Edwarsyah Efendi, R.; Safitri, E.; Idroes, R.; Heng, L.Y.; Sani, N.D. Isolation of Pectin from coffee pulp Arabica Gayo for the development of matrices membrane. IOP Conf. Ser. Mater. Sci. Eng. 2019, 523, 12014. [CrossRef]

33. Hasanah, U.; Setyowati, M.; Efendi, R.; Muslem, M.; Md Sani, N.D.; Safitri, E.; Yook Heng, L.; Idroes, R. Preparation and Characterization of a Pectin Membrane-Based Optical pH Sensor for Fish Freshness Monitoring. Biosensors 2019, 9, 60. [CrossRef] [PubMed]

34. Di Tocco, A.; Robledo, S.N.; Osuna, Y.; Sandoval-Cortez, J.; Granero, A.M.; Vettorazzi, N.R.; Martínez, J.L.; Segura, E.P.; Iliná, A.; Zon, M.A.; et al. Development of an electrochemical biosensor for the determination of triglycerides in serum samples based on a lipase/magnetite-chitosan/copper oxide nanoparticles/multiwalled carbon nanotubes/pectin composite. Talanta 2018, 190, 30-37. [CrossRef] [PubMed]

35. Pundir, C.S.; Sandeep Singh, B.; Narang, J. Construction of an amperometric triglyceride biosensor using PVA membrane bound enzymes. Clin. Biochem. 2010, 43, 467-472. [CrossRef] [PubMed] 
36. Zhu, M. Development of Triglyceride Biosensor Based on the Polydopamine-Gold Nanocomposite. Int. J. Electrochem. Sci. 2017, 12, 6863-6873. [CrossRef]

37. Narang, J.; Chauhan, N.; Rani, P.; Pundir, C.S. Construction of an amperometric TG biosensor based on AuPPy nanocomposite and poly (indole-5-carboxylic acid) modified Au electrode. Bioprocess Biosyst. Eng. 2013, 36, 425-432. [CrossRef] [PubMed]

38. Rezvani, M.; Najafpour, G.D.; Mohammadi, M.; Zare, H. Amperometric biosensor for detection of triglyceride tributyrinbased on zero point charge of activated carbon. TURKISH J. Biol. 2017, 41, 268-277. [CrossRef]

39. Safitri, E.; Heng, L.Y.; Ahmad, M.; Ling, T.L. Fluorescence bioanalytical method for urea determination based on water soluble ZnS quantum dots. Sens. Actuators B Chem. 2017, 240, 763-769. [CrossRef]

40. Mazurenko, I.; Monsalve, K.; Infossi, P.; Giudici-Orticoni, M.-T.; Topin, F.; Mano, N.; Lojou, E. Impact of substrate diffusion and enzyme distribution in 3D-porous electrodes: A combined electrochemical and modelling study of a thermostable $\mathrm{H}_{2} / \mathrm{O}_{2}$ enzymatic fuel cell. Energy Environ. Sci. 2017, 10, 1966-1982. [CrossRef]

41. Alqasaimeh, M.; Heng, L.; Ahmad, M.; Raj, A.S.; Ling, T. A Large Response Range Reflectometric Urea Biosensor Made from Silica-Gel Nanoparticles. Sensors 2014, 14, 13186-13209. [CrossRef]

42. Minakshi; Pundir, C.S. Construction of an amperometric enzymic sensor for triglyceride determination. Sens. Actuators B Chem. 2008, 133, 251-255. [CrossRef]

(C) 2019 by the authors. Licensee MDPI, Basel, Switzerland. This article is an open access article distributed under the terms and conditions of the Creative Commons Attribution (CC BY) license (http://creativecommons.org/licenses/by/4.0/). 